\title{
Politics and Economy: Local Strengths of The Bagurau Oral Literature in The Digital Era
}

\author{
K Anwar \\ Master of Literature-PPs FIB, Andalas University \\ \{khairilanwar@hum.unand.ac.id\}
}

\begin{abstract}
This study aims to explain aspects of politics and economics which became the local strength of bagurau oral literature in the digital era. This study is the result of observation of the phenomenon of bagurau oral literature that developed in West Sumatra. Bagurau is oral literature form of 'big' because it is told every night in different spaces and locations. Even on the same night there were several narrations in different places. This study uses sociological approaches, qualitative methods, and poststructuralist theories, specifically the other 'tracer' contained in bagurau. The findings of this study, that in the period leading up to the general election of presidential and legislative candidates this oral literature shows its local strength, namely political, economic and digital aspects. Political aspects, bagurau acts as a media for disseminating legislative candidates, socializing government programs, and sponsored by legislative candidates. Economic aspects, how to make a living as a authors, audience economic motivator, economic transactions of authors and audiences, aesthetic economic transactions, and economic drivers of local communities. Finally, the context of the narrative of bagurau utilizes digital for the media to create text, narrative process, and documentation, and forwarding and disseminating information about the narrative of bagurau.
\end{abstract}

Keywords: Bagurau, Local, Digital, Politics, Economics.

\section{INTRODUCTION}

Bagurau is a form of Minangkabau oral literature that developed in West Sumatra[1]. This oral literature is spoken by means of dialogue between the singer 'tukang dendang' and audience 'pagurau' accompanied by traditional Minangkabau wind instruments, called saluang. In its development improvised with modern musical instruments, namely orgen. Improvisation is carried out according to the present audience. Dialogue is indirect, because it is mediated by recirators, called tukang oyak. Especially the dialogue delivered by the audinces - the purpose of the tukang dendang or fellow audiences - must go through the tukang oyak[2]. Dialogue delivered can be in the form of direct speech or message on a piece of paper or short message 'sms'or whatsaap 'wa'. Furthermore, it is repeated or recited by tukang oyak. While the dialogue 'song' is spoken by tukang dendang direct to the audience. Every dialogue 'message' delivered by the audinces some money must be included according to oral agreement[3]. The money is a form of participation in the host holding the narrative, which is called maisi lapiek. 
Such narrative procession takes place at night from 8:00 p.m. to 4:00 p.m. The narrative was attended by local audiences and audiences from neighboring cities. Almost every night there is always a narrative and on the same night there were several narrative in place or different city, even in the same city. The intensity of the narrative is high in the digital era contains the present local power. What is local power? This is what is explained in this study.
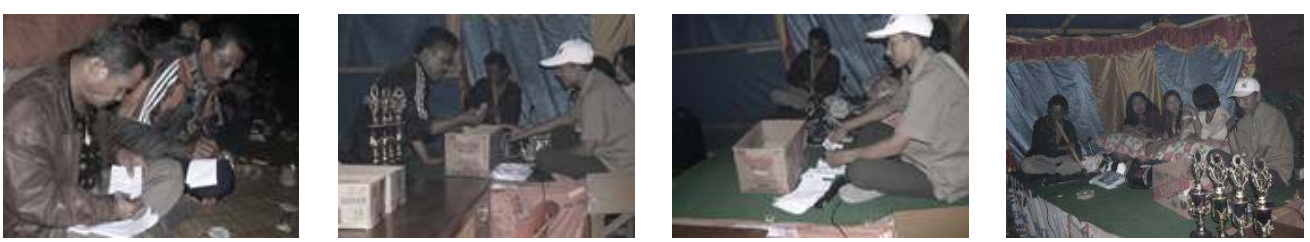

Figure 1. Procession Photo Bagurau Oral Literature

\section{RESEARCH METHOD}

This study is based on the results of observations of empirical data about the narrative bagurau oral literature. This observation has been carried out since the last 18 years, from 2000 to 2019. Because general elections are held once every five years, this data is a collection of five research data. Observation and data collection is done by recording and recording in the cultural area Luhak Nan Tigo in West Sumatra Province, covering District Tanah Datar, Agam, 50 Kota, and City Payakumbuh, Bukittinggi, and Padangpanjang. This qualitative research is carried out with a sociological approach [4], by the way participation observer. The collected data is analyzed using poststructuralist theory, specifically using the concept of trace 'the other' [5].

The narrative of bagurau oral literature is a complex consists of text and context [6] which gave birth to a discourse. The discourse is text. In theoretical terms, the text is writing consisting of traces, which can be given free meaning[7]. That meaning multiplies in accordance with the context of meaning. That meaning continues to be created because of the difference and differance in the meaning of the trace.

In addition, theoretical and economic views are also used in studying bagurau oral literature. Philosophically, politics is an effort made by someone to achieve his goal[8]. While economics is a human action to fulfill their needs through the process of demand and supply[9]. In a poststructuralist perspective[10], binary opposition and logocentrism are dead. Things that are marginalized and forgotten has the same position in the structure of a building. Political and economic aspects in the study of literature are urgent and strategic to understand the power of oral literature in the context of the digital era, industry 4.0.

\section{RESULT AND DISCUSSION}

Based on a study of bagurau oral literature data which was spoken before the general election found some local forces, namely politics, economics, and digital. These three powers is part of a factor which makes oral literature bagurau as a large oral literature. 


\subsection{Political Aspects}

The political aspect is the local power of Bagurau oral literature. That strength was seen in the days leading up to the presidential and legislative elections, both legislative candidates in the DPR, Provincial DPRD, and district / city DPRD. Previously, also in the election of mayors, regents and governors.

As for the form of local power which contains political aspects is a media socialization and sponsorship narrative from legislative candidates, presidential candidates, governor candidates, mayors / regents; and government program socialization. This aspect is reflected in the following text excerpt:

$7 \quad$ Tukang Oyak: “............ Baraliah ka pamintaan lagu Sijobang, pamintaan dari Kamaruzzaman jo kawan-kawan dari Dinas Pariwisata Kabupaten Tanah Data, baliau mamamintak lagu Sijobang, baliau bapasan malalui pantun, ‘......., Kok dibukak pusako lamo, Dibangkik batang tarandam, Lah banyak ragi nan barubah, Bulek lah ruponyo daun nipah, Buleklah nyato bapasagi, Dicaliek lipek indak barubah, Kironyo lah tabuak tiok ragi, Ka pulau kito ka pulau, Ka pulau manjariang udang, Bagurau kito bagurau, Maubek ati nan malang, Ka pulau kito ka pulau, Ka pulau manjariang bili, Bagurau kito bagurau, Untuak mampaarek silaturahmi, Luruihlah jalan ka Padang Panjang, Andak manjalang ka Sapuluah Koto, Walau banyak budayo nan datang, Kesenian Minang kito kambangan juo,' iko pasan dari Dinas Pariwisata Kabupaten Tanah Data, '..... ko pasan dinas pariwisata bana, duo puluah ribu, diagiah lagu Sijobang." (Bagurau, tanggal 25 Februari 2019).

".........Transfer to the song Sijobang, request from Kamaruzzaman and friends from the Tanah Data District Tourism Office, they asked for the song Sijobang, accompanied by a message in the rhyme, If you open an old heirloom, Immersed submerged stem, Many forms change, Round is apparently nipah leaves, The round turns are square, Viewed folding does not change, It may have been damaged on each side, To our island to the island, to the island catching shrimp, Joking us jokingly, Treating poor hearts, To our island to the island, to the island reaching the bili, Joking us jokingly, To strengthen friendship, Straight down the road to Padang Panjang, Want to go to Sapuluah Koto, Although many cultures come, Our Minang Arts is preserving too, ' this is a message from the Tanah Data District Tourism Office, '......this is a message from the Tanah Data District Tourism Office"

From the text quoted above, we can see the political policies of the government that support the preservation of bagurau oral literature. The government through the Tourism Office participates as a participant in the bagurau while delivering a message so that this local potential continues to be developed. Bagurau is not only a form of oral literature, but it is a medium of friendship for the local community and audiences 'pagurau'.

141 Tukang Oyak: “........ Salamaik datang Pak Nofrizon Wakil Sekretaris Partai Demokrat Propinsi Sumatera Barat, Datuak Maruhun sarato Datuak Rajo Imbang jo rombongan, kahadiran Mamak Dunsanak kami ucapkan tarimo kasih. Tolong Wit, sapuluah ribu rupiah!" (Bagurau, 25 Februari 2019)

“........ Welcome Pak Nofrizon Vice Secretary Partai Demokrat Propinsi Sumatera Barat, Datuak Maruhun and Datuak Rajo Imbang and group, for attendance Mamak Dunsanak We would like to express our gratitude. Please Wit, ten thousand rupiah!"

146 Tukang Oyak: “....... Op! Batanyo Buyuang Rimbo, ka Datuak Rajo Imbang, jo Mak Datuak Maruhun, 'di ma batinggaan Mak Datuak Cinangka, kok sairiang jo Pak Nofrizon kini?' Ko pasan Buyuang Rimbo. Kato bajawek ka Buyuang Rimbo, 'Datuak Rajo Imbang, Datuak Maruhun jo Pak Nofrizon, baliak main poli di Kubu Karambia Batipuah, dalam rangka turnamen voli bal se Sumatera,' ....... Bapasan ka Buyuang Rimbo, sapuluah ribu, dari Pak Nofrizon, 'alhamdulillah, lai manang main voli sa Sumatra, di Batipuah bana cako ..........” (Bagurau, 25 Februari 2019) 
“....... Op! Buyuang Rimbo ask to Datuak Rajo Imbang and Mak Datuak Maruhun, 'where Mak Datuak Cinangka abandoned, why along with Pak Nofrizon now?' This is the message Buyuang Rimbo. Answer to Buyuang Rimbo, 'Datuak Rajo Imbang, Datuak Maruhun and Pak Nofrizon the new back playing vooly ball in Kubu Karambia Batipuah, in the framework of the volly ball tournament se Sumatera,' .......' Message to Buyuang Rimbo, ten thousand, from Pak Nofrizon, 'alhamdulillah, become champion volly ball seSumatra in Batipuah this afternoon...

In the quote text 141, and 146 above, it shows a political figure from certain parties that have competed in the 2019 elections. The character is narrated as an activist who cares towards sports activities at the same time bagurau oral literature. He helped accompany sportsmen to compete. His concern for the constituents and arts of the Minangkabau tradition evidenced by his arrival and participation in narrating bagurau oral literature.

In the following picture, on the background stage, a banner is attached from a large political contestant who sponsored the narrative of bagurau oral literature.

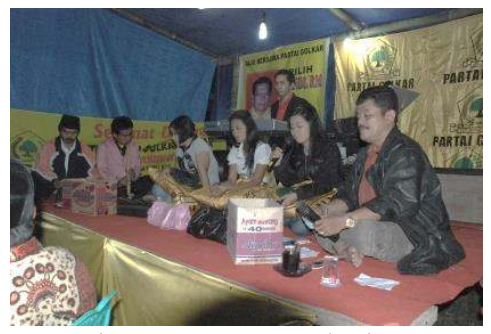

Figur 2. Photo The Narrative Bagurau Oral Literature with Background Stage Sponsor of Political Figures and Parties (Doc. Khairil Anwar)

Political content in bagurau oral literature is not something taboo. It is precisely with the political momentum of oral literature that bagurau participates and demonstrates the functional nature of the lives of the people and the collective society and the nation and state.

\subsection{Economic Aspect}

Economic aspects are part of the local power of in bagurau oral literature. This aspect is very thick in the phenomenon of bagurau narrative. When it will be planned to say, economic activity has shown its form. And so on until the end of the narrative.

Before the narrative began, economic transactions had taken place between the host who would hold the narrative with tukang dendang, tukang saluang, dan tukang oyak. The transaction took place at a coffee shop, a place agreed to by the community 'Pagurau Luhak Nan Tigo'. There are several coffee shops that are the place of transaction as well as the information center for organizing narrative speeches, namely, "Sianok" Coffee Shop in Payakumbuh City, "Tigo Roda" in the City of Bukittinggi, and "Saraso" in Batusangka. The transaction agreed on the amount of payment that must be provided for one night's narrative from 8:00 p.m. to 4:00 p.m. The agreed amount of honorarium is Rp. 300,000 / person. The total that must be paid is relative, depending on the number of the desired tukang dendang. For example, if you are asked by 3 tukang dendang, the host must pay Rp. 1,800,000.-. Why is that amount, because they have to pay honorariums for tukang saluang and tukang oyak and single organ players.

When the narrative takes place there are also economic transactions, namely aesthetic transactions. This transaction occurs to meet oral literary conventions,namely maisi lapiek. This 
convention is a form of participation in narrative. Every member of the community Pagurau Luhak Nan Tigo feel called to contribute. Participation is manifested in the form of the creation of bagurau oral literary texts. Every text that is created must be accompanied by 'paid' with a donation of money. This can be seen from recitation by tukang oyak which mentions the amount of money after reading messages from the public, like the text quoted below.

121 Tukang Oyak: 'Sanabu lai lah Reni! ..... 'baa kok bantuak serak bunyi saluang,' iko pasan dari Akang bana, duo puluah ribu. Sudah tu, tambah pulo pasan dari Unyuik ciek, bapasan ka Doni, 'baa kok jauah bana manuang kini, dek Mamak Efendi indak tibo ndak,' iko pasan dari Unyuik, sapuluah ribu. 'Bialah Mak Abaih di balakang,' aa iko pasan Mak Abaih, 'dari jauah Mak Abaih mancaliek, 'iko pasan Mak Abaih, Agam juo naiak, sapuluah ribu. Sudah tu, dari Grup Arimau Singgalang, mamintak Rimbo Panjang jo Rantau Barangin, tatanda Arimau Singgalang, limo puluah ribu. Dari Akang, bapasan Campua Baua ka Agam, 'naiakan Doni di ujuang pantun!' sapuluah ribu. ......... " (Bagurau, 25 Februari 2019).

"Reni repeated once more! ..... why is it bad sound saluang,' this message from Akang, twenty thousand. After that, added massage from Unyuik the massage to Doni, 'why humming, because Mamak Efendi not yet come,' this massage from Unyuik, teen thousand. 'So be it Mak Abaih is behind,' aa this message Mak Abaih, 'from afar Mak Abaih look at,' this is message Mak Abaih, Agam again singing, ten thosand. Next, from Grup Arimau Singgalang, request song Rimbo Panjang jo Rantau Barangin, signed Arimau Singgalang, fifteen thousand. From Akang, message to Campua Baua to Agam, 'singing Doni at the end of the rhyme!' teen thousand.

Aesthetic transactions in the narrative of bagurau oral literature are relatively the amount depending on the number that appears first. There is no standard rule that must contribute a certain amount. Any number will be accommodated in the narrative. However, a large number will be listed in text. Sometimes the host hints to tukang oyak to mention a larger amount fictitiously in its recitation. This is useful for provoking the emotions of audiences to contribute more.

Table 1. Transactions and Nominal Amounts in Bagurau Oral Literature Procession

\begin{tabular}{|c|c|c|c|}
\hline NO & TRANSACTION NAME & TRANSACTION CONTENT & TOTAL (RP) \\
\hline 1 & Massage and Request Song & Mamintak lagu (Request Song) & $\begin{array}{l}50.000- \\
100.000\end{array}$ \\
\hline 2 & $\begin{array}{l}\text { Message and Continue } \\
\text { Song }\end{array}$ & $\begin{array}{l}\text { Papanjang pantun (Continue } \\
\text { poetry/song) }\end{array}$ & $10.000-20.000$ \\
\hline 3 & Message & Gurauan (Jokes) & $5.000-10.000$ \\
\hline
\end{tabular}

Besides that, around the location of the narrative of oral literature, there were also economic transactions. Economic activity is created by the presence of a shocked market or an existing shop. In the shop there is a transaction to meet the needs of the public for various snacks and drinks.

Outside of narrative events, during the day the public is involved with economic activities, such as traders, farmers, laborers and employees. Because of oral literary conventions that require audiences to contribute so they work harder to get money. Thus, oral literature encourages audiences to be economically productive.

Overall, in one narrative of Bagurau oral literature from the plan to the end of the money turnover. The real amount seen is honorarium and operational costs of approximately Rp. $2,000,000$. If the level of money collected from donations from the audience is approximately 
Rp. 2,500,000,- then the remaining surplus is Rp. 500,000,- Of course the number of transactions in the shops has not been monitored.

The narrative of oral literature for almost every night. There are even two or three shows on the same night in different locations. Except in the holy month of Ramadan there is no narrative. That is, in one year there were approximately 330 narrations. Thus, in one year the narrative of oral literature spreads around Rp. 825,000,000 (2,500,000 x 330). Large amounts of capital are empowered by the narrative of an oral literature. Countless numbers have been circulated outside the narrative.

Tabel 2. Bagurau Oral Literature One-time Balance Sheet (dalam Rupiah)

\begin{tabular}{|c|c|c|c|c|c|}
\hline NO & DESCRIPTION & TOTAL & NO & DESCRIPTION & TOTAL \\
\hline 1. & Start Modal & 500.000 & 1. & Honour Tukang & \\
\hline \multirow{6}{*}{2.} & Donations Collected & 2.500 .000 & & Dendang, Saluang, and & 1.800 .00 \\
\hline & & & 2. & Oyak & \\
\hline & & & 3. & Narrative Operational & 200.000 \\
\hline & & & & Saldo & 1.000 .00 \\
\hline & & & & & $\frac{0}{200000}$ \\
\hline & Total & 3.000.000 & & Total & 3.000 .00 \\
\hline
\end{tabular}

\subsection{Digitalization}

Originally the narrative was traditional in utilizing the potential around it. For the creation of text, in addition to direct speech and using paper found around the narrative arena, such as paper wrapped in food wrap or cigarettes. In its development, the committee prepares special paper, such as paper books or HVS.

In the industrial era 4.0, the creation of texts in narrating bagurau oral literature also utilizes digital tools in the form of smartphones to deliver messages and requests as well as information about narrative. So that information about narrative oral literature quickly spread. At the narrative location sometimes audiences send messages via sms or whatshaap, especially from afar because it is unable to come at the narrative location. In addition, the audience often digitizes the narrative of oral literature in an independent manner for the benefit of personal documentation and disseminating information about the conditions at that time to other audiences who have not or cannot come on location that night. Digitalization concerns will weaken the position of narrative of bagurau oral literature as the essence of friendship and participation in the continuation of culture and sustainable development[11].

The political, economic and digital traces is an instrument of the process of interpreting bagurau oral literature. Trail hybridity is a form of madness and ecstasy of the public who are committed to the continuity of the Minangkabau culture. Public acceptance of differences in political choice is a characteristic of fundamental pluralism in Minangkabau society[12]. Pride contributing to the collective is a noble attitude. Material donations are the results obtained from work. Because in its ideology in individual assets there are also rights of others. It has been formed in the rantau as a Minangkabau social institution[13]. Similarly, the use of digital tools is a form of competition with the world of others. 


\subsection{Discussion}

The study of oral literature has been going on for a long time. Many studies have been produced, especially about structure, function, composition, formula, distribution, orality and local genius[14]. Previous studies still use the structuralist paradigm[15]. However, the study of the relevance of oral literature with current politics, money, and digitalization is still small, perhaps not yet available. This latest study uses the poststructuralist paradigm, with observations on the narrative of the latest oral literature for the period leading up to the 2019 Indonesian general election.

\section{CONCLUSIONS}

One indicator that makes oral literature bagurau still exist in its community is its ability to meet the present audience, namely political, economic and digital aspects. If oral literature has no contribution to the community, then oral literature will be abandoned and degraded from the lives of the people and local cultural assets. Of course this is a big loss for the community because of the extinction of one aspect of its culture.

Politically, oral literature is acceptable to the political activities of the audience directly. Is it used as a media for socialization or promotion, or directly sponsored by political figures. There were no conflicts and friction between people due to different political streams as seen on social media so that they were subject to IT criminal sanctions. Audiences realize that oral literature emphasizes aesthetics and friendship. Economically, bagurau oral literature is a large social capital and contains a moral green character for sustainable development. Similarly from the digital aspect, bagurau oral literature digitizes the process of telling and disseminating information.

\section{ACKNOWLEDGEMENTS}

To the Rektor Andalas University and Chairman of the Andalas University LPPM, thank you for helping to publish this study and facilitate training in making indexed articles. Thanks are also conveyed to authors and audiences of bagurau oral literature in Luhak Nan Tigo, Sumatera Barat. They have accompanied and received researchers as part of the narrative community in various locations. This makes it easier for researchers to conduct research.

\section{REFERENCES}

[1] A. Amir, Zuryati, and K. Anwar, Pemetaan Sastra Lisan Minangkabau. Padang: Andalas University Press, 2006.

[2] K. Anwar, I. W. Cika, I. N. K. Ratna, and I. N. W. Kusuma, "Bagurau: Minangkabau Oral Literature In Luhak Nan Tigo West Sumatera,” e-Journal Linguist., no. Vol. 4. Juli 2010 No. 2, 2010.

[3] K. Anwar, "The Economics Strenght in Minangkabau Oral Literature," in Sixth International Conference on Languages and Arts, Universitas Negri Padang, 2017.

[4] N. K. Ratna, Teori, Metode, dan Teknik Penelitian Sastra. Yogyakarta: Pustaka Pelajar, 2004.

[5] Y. A. Piliang, Hipersemiotioka. Yogyakarta: Jalasutra, 2003. 
[6] F. Ruth, Oral Poetry. London: Cambridge University Press, 1979.

[7] M. Al-Fayyadl, Derrida, 2nd ed. Yogyakarta: LKiS, 2006.

[8] C. Holt, Ed., Culture and Politics in Indonesia. Jakarta - Kuala Lumpur: Equinox Publishing, 2007.

[9] A. Romarina, "Economic Resilience Pada Industri Kreatif Guna Menghadapi Globalisasi Dalam Rangka Ketahanan Nasional,” J. Ilmu Sos., no. Vol 15 No. 1, pp. 35-52, 2016.

[10] R. Harland, Superstrukturalisme. Yogyakarta: Jalasutra, 2006.

[11] K. Anwar, "Oral Tradition (Literature): Conservation Of Ecology And Promotion Of Tourism Destination,” J. Magistra Andalusia, no. Vol I No 1, pp. 14-20, 2019.

[12] F. von Benda-Beckmann, Runtuhnya Tangga Mufakat. Jakarta: Rajawali Press, 1995.

[13] M. Naim, Merantau, Pola Migrasi Suku Minangakabau. Yogyakarta: UGM Press, 1979.

[14] S. Y. Sudikan, Metode Penelitian Sastra Lisan. Mojokerto: Satya Wacana, 2017.

[15] M. Sarup, Poststrukturalisme dan Posmodernisme. Yogyakarta: Jalasutra, 2008. 